By MAURICE F. TAUBER

\title{
Reorganizing a Library Book Collection-Part I
}

Dr. Tauber, assistant director, Technical Services, Columbia University Libraries, presents in this and a succeeding article some of the issues that arise in reorganization.

$I^{N}$ EARLIER PAPERS attention has been college and university libraries ${ }^{1}$ and the reasons for recataloging and reclassification. ${ }^{2}$ Consideration has also been given to special problems in reclassification, ${ }^{3}$ and mention has been made of managerial problems. ${ }^{4}$ What, then, is the need for additional papers on technical reorganization of a library? This paper has been prepared because recent inquiries to the writer lead him to believe that a description and analysis of the actual processes and routines of recataloging and reclassification would be useful to some librarians during the period of the war. ${ }^{5}$ With most foreign book markets

1 Tauber, Maurice F. "Classification of Books in College and University Libraries: Historical Aspects."

Library Quarterly 12:706-24, July 1942. lege and University Libraries: Reasons and Evaluation." Library Quarterly I $2: 82^{\prime} 7 * 45$, October 1942.

"Special Problems in Reclassification and Recataloging." College and Research Libraries 4:49-56, December 1942.

"Reclassification of Special Collections in College and University Libraries Using the Library of Congress Classification." Special Libraries 35:

I 1 1 - 15, 139, April 1944.

"Reclassification and Recataloging of Materials in College and University Libraries." In William M. Randall, ed. The Acquisition and Cataloging of Books. University of Chicago Press, I940, p. 187-219. See also MacPherson, Harriet D. "Re. classification of College and University Libraries." College and Research Libraries $1: 159-64$, March 1940.

5 Data used in this paper were collected by question. naire from a group of sixty college and university libraries in the United States and Canada. For a list of these libraries, see the article in Special Libraries, cited in note 3 above, p. 139 closed and with a reduction in domestic publications, some librarians are reorganizing their collections so that improved service will be available to their patrons in the future. In some library systems considerable consolidation of collections is taking place. It is necessary to repeat, however, that any plan of reorganization should be carefully considered, since the costs are relatively high.

The technical problems present in projects of recataloging and reclassification are many and complex. These problems are concerned with matters of policy as well as with procedures and elements in the processes. In matters of policy, such questions as the following should be considered: Will an attempt be made to reclassify and recatalog the whole collection quickly and efficiently by a special temporary staff or will the work be performed gradually by the regular staff along with the handling of new accessions? It is apparent that during the war, when personnel is scarce, temporary staffs are almost impossible to obtain. Will the new classification or new subject headings be applied to new books, to books in special subject fields, or to books in the whole collection? It seems clear that the size and type of the existing collection will directly affect the policy which can be pursued.

The procedures concerned with how the work is to be done, like questions of policy, depend upon the nature of the collection 
and the physical layout of the technical and service departments. Major problems which the librarian will need to settle may be grouped into two categories: (I) matters of general concern and (2) mechanics of the processes. Under the first grouping, decisions regarding the following factors may need to be made: (a) organization of the work, (b) working quarters, supplies, and equipment, (c) handling of the book collections, (d) attention to users, and (e) special problems. Each of these factors of course is directly related to the question of staff organization, which will be discussed briefly. Except for special problems, which have already been treated, ${ }^{6}$ the following sections discuss each factor in relation to technical reorganization. Routines or the mechanics of the processes, will be treated in a paper to appear later.

\section{Organization of the Work}

Whether or not to maintain a separate reclassification unit is a first consideration in the organization of the project. At the New York Public Library a separate unit of the preparation division, known as the recataloging section, handles all the recataloging of all nondocument closed-entry material. During the reclassification of the University of Rochester Library a separate division for the work was set up. In the first case, we have an example of a special group of individuals concerned with the continual revision of the cataloging in a large library. When the card catalogs total millions of cards the records are likely to reflect a greater number of specific errors and inconsistencies than smaller catalogs. Except in large libraries, however, the need for a special unit engaged only in recataloging is rare. In the matter of a separate reclassification department designed to

- Tauber, Maurice F. "Special Problems in Reclassification and Recataloging." College and Re. search Libraries 4:49-56, December 1942. carry on the special job of rearranging and reorganizing a whole library collection, however, another problem is presented.

The questions which arise in connection with a separate reclassification department involve the organization of the unit, the personnel, and its relation to the permanent classification and cataloging work. Separate reclassification departments have been established in a number of libraries. However, in many of these, because of lack of funds, the separate department has been abandoned. It may be generally concluded, nevertheless, that in those libraries in which separate units were maintained, the work of reorganization has gone on more rapidly and consistently than in those in which the project was conducted on a "fill-in" basis.

The organization of cataloging and classifying in a library is generally one of two types: (I) classifying is in the hands of an individual (or several individuals) who perform no cataloging and (2) the two processes are combined in the work of catalogers. A more recent division of the work is to have descriptive cataloging performed by one group and subject cataloging and classification by another group. In most libraries cataloging is combined with classifying in the hands of several catalogers. Donald Coney, who investigated the division of the processes in a group of libraries, found that fifty-three out of sixty-two followed the third procedure, that is, the catalogers performed all tasks connected with preparing a book for the shelves. ${ }^{7}$ In only four instances did the present system of separation of activities result from a reclassification department set up for the purpose of reorganizing the technical processes. The professional opinion offered in this survey clearly indicated that more economical and more uniform results were obtained by combining classification with subject head-

7 These data used with permission of $\mathrm{Mr}$. Coney. 
ing work in the hands of the catalogers. The experience of libraries which have attempted to separate the processes has not always been unsuccessful, but it is probably more expensive. A cost study of the different types of organization is necessary to determine which type of organization is the more efficient.

\section{Working Quarters, etc.}

No program of reorganization which has been planned carefully will fail to take into account the physical resources necessary for efficiency. The director of a project of reorganization should settle such problems as locating the quarters for various aspects of the work; providing supplies, mechanical equipment, and bibliographical and reference tools; and preparing a departmental manual of policies and decisions.

It is obvious that the physical arrangements of the library building will determine whether or not the work of reclassification and recataloging can be carried on in the catalog room, in the stacks, in a special room, or in the bindery. Although not always obtainable, close proximity of the quarters in which the reclassification is carried on to the card catalogs and the stacks is highly desirable. The constant traffic to and from the stacks to consult and get books, and to the card catalogs to consult and get cards in order to rearrange thousands of volumes, requires considerable effort on the part of both the professional and clerical staffs. Moreover, the addition of new assistants to perform the activities of reclassification may necessitate the rearrangement of work space and the addition of desks and equipment. Of course, during war times it may not be possible to secure adequate personnel or equipment.

One of the important problems is the utilization of space in such a manner that no confusion will result in the handling of new acquisitions and the rehandling of materials from the stacks. Several possibilities in the arrangements of the physical quarters for the handling of reclassification and recataloging have been followed and may be discussed briefly.

The first possibility is to confine technical reorganization to the catalog department. This is the obvious arrangement and has been followed in most libraries. If the quarters are adequate and the reclassification does not interfere with the normal preparation of new materials, this plan should be entirely satisfactory. It eliminates the need for duplicating reference books and mechanical equipment. The provision of special shelving in the general catalog room for the handling of reclassified materials, however, may be necessary.

The second procedure is to work directly upon the books in the stacks, while card work is handled in the catalog department. On a large project this procedure may require special working arrangements for the removal of old numbers from books and cards and for retyping and remarking. It has the advantage of keeping the old stock from the new. The amount of traffic through the technical departments is definitely decreased. Some inconvenience is offered by the lack of reference tools and other equipment and by distance from the shelflists, authority files, or other records.

The third scheme provides for a special room for reclassification. This sometimes presents difficulties. Unless the special room is in close proximity to the catalog room, the card catalog, and the stacks, any advantage that is obtained through the isolation of the processes may be overshadowed by the difficulties presented to the reclassification staff. The principal advantage of this arrangement is the segregation of the reclassification from the handling of new acquisitions. In large libraries which ac- 
quire thousands of volumes annually this may be effective.

The bindery has also been used as a place to carry on the routines of reclassification and recataloging. This arrangement does not differ much from the one discussed in the preceding paragraph. It has one advantage not found in other accommodations, namely, the facilities for the quick repair of torn books and for the mechanical marking or stamping of volumes.

A final procedure, which has been followed in smaller libraries with limited staffs, is to perform the work on reclassification in various parts of the building, e.g., catalog room, circulation desk, and reference desk. Reclassification in libraries using this procedure is usually a process carried on in slack times, becoming busy work for attendants who are not charging books or answering reference questions. The possibilities for error, inconsistency, and duplicated effort are high under this arrangement. To use student assistants concentrated in the catalog department appears to be a more efficient approach to the problem in the smaller library. It is true, however, that in institutions which do not have summer sessions, reclassification can be carried on during the summer months by the whole staff with considerable success. Periods between semesters or during holidays may also be used by the whole staff to participate in a project of reorganization.

\section{Mechanical Aids}

Attention should be given to the possibilities of mechanical aids in reclassifying and recataloging. While the electrical eraser has been used in many libraries engaged in reclassifying and recataloging, a number of them still dawdle along with razor blades or library scratchers. The possibilities of devising an electrical eraser which would automatically remove call numbers and subject headings is not remote, particularly since many libraries place such information in approximately the same places on cards. Librarians have not taken seriously the suggestion by Bliss that markings on books should be made in such a temporary way that they may be easily removed.

Reclassification on a large scale requires the provision of adequate work tables, shelving, trucks, typewriters, marking supplies, and catalog trays. A careful examination of the routines involved in reorganization will indicate that greatest efficiency will be obtained when the books move along in a continuous line. This requires careful marking of units involved in the work.

\section{Tools for Reorganization}

While reference and bibliographical tools are necessary in ordinary daily cataloging and classification, they are particularly valuable in increasing speed and reducing costs of operation during reorganization. Such standard tools as the United States Catalog, of course, are indispensable in libraries which are attempting to order new sets of printed cards for manuscript or typewritten cards. Access to a depository catalog should also be taken advantage of when possible. Among the types of tools which have been found lacking in some libraries engaged in reclassification are the United States Catalog series, depository catalogs, foreign dictionaries and encyclopedias, and biographical dictionaries.

The operational activities in reclassification and recataloging usually have not been set apart in special or departmental manuals of catalog departments. Perhaps such records are not necessary. In libraries which have reduced their special techniques and routines of reclassification to written form, however, it has been found that errors have been minimized and consistency has 
been maintained. Once the procedures of reorganization have been determined, the important problem is to keep the policy flexible enough to absorb new personnel.

The decisions regarding the handling of book collections during the reorganization are of utmost importance, both for the technical aspects of the immediate problem and for the future work of the departments concerned with technical processes in the library. What is to be done with branch or departmental collections? Are all books to be reclassified? Will older volumes be discarded or segregated? What are the best procedures under certain conditions in the handling of problems arising from lost books, charges to faculty members and students, books at the bindery, and books on reserve? All these questions need consideration by the librarian and the supervisor of reorganization.

\section{Special Collections}

Special collections usually require special attention under ordinary conditions of work. By a "special collection" is meant a collection on a particular subject or subjects segregated from the regular book collection, whether within the stack or in separate rooms or buildings. The problem usually faced is to decide whether or not the special collection is to be reclassified and, if it is, whether or not the new classification adopted is similar to that used for the other parts of the collection.

Most librarians apparently have found it satisfactory to reclassify their special collections along with the central collections. They have also concluded that confusion is reduced to a minimum if only one system is used for all collections. This, of course, is not always the case. In some instances, the retention of a special collection in its original classification will serve the purposes of the library as well as the system adopted for the central collection. This is definitely true of a special collection which is inactive.

The question of reclassifying departmental collections falls into a category similar to the one for handling special collections. The decision to reclassify a departmental library depends largely upon the relationship of the departmental library to the central library, as well as upon the nature of the collection. If the departmental library is part of the central system, receives service from a centralized cataloging unit, and the collection is growing consistently, then it seems that reclassification would in the long run insure greater technical efficiency on the one hand and ease of use on the part of the patrons and staff, on the other. In the majority of libraries faced with this problem the practice has been to reclassify and recatalog departmental collections. Notable exceptions have been law and medical collections.

\section{Older and New Materials}

No attempts have been made on a grand scale to differentiate between older materials and new materials in reclassifying projects. In one instance a large library started reorganization with the intention of reclassifying materials acquired after a certain date. This policy has since been abandoned, however, and plans have been made to reclassify the whole collection. The fact that insufficient data are available on the nature of the materials used, except perhaps in broad classifications, has not made it possible for librarians to devise criteria for segregating or rejecting materials. The investigation of the problem of obsolescence among library materials might well suggest workable procedures in the matters of segregation and storage. ${ }^{8}$

- See Gosnell, Charles F. "Obsolescence of Books in College Libraries." College and Research Libraries 5:115.25, March 1944; also Logsdon, R. H. "The Instructional Literature of Sociology and the Admin. istration of College Library Book Collections." (Unpublished Ph.D. dissertation, University of Chicago, 1942.) 
Reclassification generally has served as a means to inventory carefully the whole collection of the library. In practically every library many titles which were considered lost were located during reclassification. Those titles which were found to be definitely missing were either removed from the records or replaced. A technical difficulty develops in the problems of charges to faculty members and students, books at the bindery, and books on reserve. The proper procedure apparently in all these situations is to wait until the materials have been returned to the shelves before any attempt is made to reclassify them. In cases where faculty members have books out for months or years there seems to be no reason why they should not be recalled for purposes of reclassification. In all cases the librarian should strive to serve the users rather than consider the momentary efficiency of the process. Under the best conditions reorganization is disruptive to the easy use of library materials.

\section{Attention to Users}

It has been assumed that technical reorganization of a library is aimed at eventually giving better service to the patron. Hence, it behooves the librarian to consider all possible means of enabling the user to maintain continuous access to materials during the period of reorganization. The policy should consider such problems as records for the circulation department while the books are being worked upon, records for the card catalogs which indicate to the users and the staff members that the library contains certain titles even though they are temporarily out of active circulation, guides for the accessible stacks to show the users which sections are being reclassified, and indications that materials on a certain subject may be found in more than one place in the stacks. The routines within the catalog department, or in any other place in which reclassification and recataloging are being done, should be complete to the extent that a book may be readily located.

\section{Summary}

From the foregoing comments it seems clear that the librarian will need to plan a project of reorganization carefully if he expects to make full use of personal, physical, and financial resources. Insofar as personnel are concerned, the librarian will need to differentiate carefully between professional and clerical help. Professional staff members should not spend their time on such tasks as withdrawing cards from the catalogs. In order to take full advantage of equipment, supplies, and bibliographical tools, technical reorganization of a collection is probably more effectively done in the catalog department than elsewhere. Mechanical devices should be employed wherever practical.

The addition of new types of catalogs or the introduction of a new filing code should be considered in the light of the peculiar conditions of the libraries. Necessary catalogs should always be started at the outset of operations, and simplification of filing might well benefit the users. Adequate attention should be given to the problems of users during reorganization, so that continuous service will be offered.

(to be concluded) 